\title{
Papers
}

\section{Environmental tobacco smoke and tobacco related mortality in a prospective study of Californians, 1960-98}

\author{
James E Enstrom, Geoffrey C Kabat
}

\begin{abstract}
Objective To measure the relation between environmental tobacco smoke, as estimated by smoking in spouses, and long term mortality from tobacco related disease.

Design Prospective cohort study covering 39 years. Setting Adult population of California, United States. Participants 118094 adults enrolled in late 1959 in the American Cancer Society cancer prevention study (CPS I), who were followed until 1998. Particular focus is on the 35561 never smokers who had a spouse in the study with known smoking habits.

Main outcome measures Relative risks and 95\% confidence intervals for deaths from coronary heart disease, lung cancer, and chronic obstructive pulmonary disease related to smoking in spouses and active cigarette smoking.

Results For participants followed from 1960 until 1998 the age adjusted relative risk (95\% confidence interval) for never smokers married to ever smokers compared with never smokers married to never smokers was 0.94 (0.85 to 1.05 ) for coronary heart disease, 0.75 (0.42 to 1.35) for lung cancer, and 1.27 (0.78 to 2.08) for chronic obstructive pulmonary disease among 9619 men, and 1.01 (0.94 to 1.08 ), 0.99 (0.72 to 1.37 ), and 1.13 (0.80 to 1.58), respectively, among 25942 women. No significant associations were found for current or former exposure to environmental tobacco smoke before or after adjusting for seven confounders and before or after excluding participants with pre-existing disease. No significant associations were found during the shorter follow up periods of 1960-5, 1966-72, 1973-85, and 1973-98.

Conclusions The results do not support a causal relation between environmental tobacco smoke and tobacco related mortality, although they do not rule out a small effect. The association between exposure to environmental tobacco smoke and coronary heart disease and lung cancer may be considerably weaker than generally believed.
\end{abstract}

\section{Introduction}

Several major reviews have determined that exposure to environmental tobacco smoke increases the relative risk of coronary heart disease, based primarily on comparing never smokers married to smokers with never smokers married to never smokers. The American Heart
Association, the California Environmental Protection Agency, and the US surgeon general have concluded that the increase in coronary heart disease risk due to environmental tobacco smoke is 30\% (relative risk 1.30). ${ }^{1-3}$ Meta-analyses of epidemiological studies have reported summary relative risks (95\% confidence intervals) of 1.30 (1.22 to 1.38 ), 1.25 (1.17 to 1.32 ), and 1.25 (1.17 to 1.33 ) for coronary heart disease ${ }^{4-6}$ and 1.23 (1.13 to 1.35 ) and 1.23 (1.13 to 1.34 ) for lung cancer, ${ }^{78}$ similar to the 1.20 found by the California Environmental Protection Agency and the US surgeon general..$^{2}$ The US Environmental Protection Agency has classified environmental tobacco smoke as a known human carcinogen. ${ }^{7}$ Chronic obstructive pulmonary disease, primarily asthma, bronchitis, and emphysema, has been associated with exposure to environmental tobacco smoke, but the evidence for increased mortality is sparse. ${ }^{23}$

Although these reviews come to similar conclusions, the association between environmental tobacco smoke and tobacco related diseases is still controversial owing to several limitations in the epidemiological studies. ${ }^{9-14}$ Exposure to environmental tobacco smoke is difficult to measure quantitatively and therefore has been approximated by self reported estimates, primarily smoking history in spouses. Confounding by active cigarette smoking is so strong that the association with environmental tobacco smoke can only be evaluated among never smokers. The relation between tobacco related diseases and environmental tobacco smoke may be influenced by misclassification of some smokers as never smokers, misclassification of exposure status to environmental tobacco smoke, and several potential confounders. It is also unclear how the reported increased risk of coronary heart disease due to environmental tobacco smoke could be so close to the increased risk due to active smoking $(30 \%$ and $70 \%$, respectively), since environmental tobacco smoke is much more dilute than actively inhaled smoke.

Most epidemiological studies have found that environmental tobacco smoke has a positive but not statistically significant relation to coronary heart disease and lung cancer. Meta-analyses have combined these inconclusive results to produce statistically significant summary relative risks. ${ }^{4-8}$ However, there are problems inherent in using meta-analysis to establish a causal relation. ${ }^{9-14}$ The epidemiological data are subject to the limitations described above. They have not been collected in a standardised way, and some relative risks 
Table 1 Follow up details of 51343 men and 66751 women in California cancer prevention study (CPS I) cohort

\begin{tabular}{|c|c|c|c|c|}
\hline \multirow[b]{2}{*}{ Follow up category } & \multicolumn{2}{|c|}{ Total cohort } & \multicolumn{2}{|c|}{ Never smokers* } \\
\hline & Men & Women & Men & Women \\
\hline \multicolumn{5}{|l|}{1 Jan 1960: } \\
\hline Dead, deleted from file (1 Oct to 31 Dec 1959) & 22 & 14 & & \\
\hline Alive, completed 1959 questionnaire (1 Oct 1959 to 31 Mar 1960) & 51321 & 66737 & 9619 & 25942 \\
\hline \multicolumn{5}{|l|}{31 Dec 1965: } \\
\hline Dead, ICD codes (1 Jan 1960 to 31 Dec 1965) & 4907 & 3506 & 685 & 868 \\
\hline Dead, no ICD codes(1 Jan 1960 to 31 Dec 1965) & 45 & 47 & 7 & 13 \\
\hline Withdrawn (1 Jan 1960 to 30 Sep 1965)† & 718 & 974 & 79 & 257 \\
\hline Lost (1 Jan 1960 to 31 Dec 1965) $\ddagger$ & 31 & 49 & 4 & 13 \\
\hline Alive, completed Sep 1965 questionnaire & 44757 & 61079 & 8574 & 24077 \\
\hline Alive, follow up to 31 Dec 1998 & 863 & 1082 & 270 & 714 \\
\hline \multicolumn{5}{|l|}{31 Dec 1972: } \\
\hline Dead, ICD codes(1 Jan 1960 to 31 Dec 1972) & 12295 & 9446 & 1865 & 2634 \\
\hline Dead, no ICD codes (1 Jan 1960 to 31 Dec 1972) & 146 & 160 & 19 & 41 \\
\hline Withdrawn (1 Jan 1960 to 30 Sep 1971)† & 1222 & 2825 & 164 & 984 \\
\hline Lost (1 Jan 1960 to 31 Dec 1972) & 1525 & 3367 & 269 & 1103 \\
\hline Alive, completed Sep 1972 questionnaire & 26070 & 37926 & 5455 & 16171 \\
\hline Alive, follow up to 31 Jan 1998 & 10063 & 13013 & 1847 & 5009 \\
\hline \multicolumn{5}{|l|}{31 Dec 1998: } \\
\hline Dead, ICD codes (1 Jan 1960 to 31 Dec 1998) & 37554 & 36669 & 6673 & 13160 \\
\hline Dead, no ICD codes (1 Jan 1960 to 31 Dec 1998) & 2456 & 2722 & 464 & 1130 \\
\hline Withdrawn (1 Jan 1960 to 30 Sep 1972) $\dagger$ & 1395 & 5450 & 197 & 2105 \\
\hline Lost (1 Jan 1960 to 31 Dec 1998) & 2962 & 6953 & 560 & 2579 \\
\hline Alive, correctly completed 1999 questionnaire & 2290 & 4869 & 681 & 2413 \\
\hline Alive, matched with California driver's licence and not known dead§ & 4664 & 10074 & 1044 & 4555 \\
\hline
\end{tabular}

${ }^{*}$ Never smokers who had spouse in cohort with known smoking habits.

tFurther follow up not possible because of incomplete or missing name on 1972 master database.

‡Complete name on 1972 master file and no match with California driver’s licence file, California death file, or social security death index until 1998.

§Based on 1990-9 match with California driver's licence file and no death match with California death file or social security death index during 1960-98.

have been inappropriately combined. Because it is more likely that positive associations get published, unpublished negative results could reduce the summary relative risks. Also, the meta-analyses of coronary heart disease omitted the published negative results from the large American Cancer Society cancer prevention study (CPS I). ${ }^{10}{ }^{11}$ We have extended the follow up for the California participants in this cohort, analysed the relation between environmental tobacco smoke and tobacco related diseases, and addressed concerns about this study.

\section{Methods}

CPS I is a prospective cohort study begun by the American Cancer Society in October 1959 and

Table 2 Personal and lifestyle characteristics of male 1959 never smokers in California cancer prevention study (CPS I) cohort by smoking status of spouse

\begin{tabular}{|c|c|c|c|c|c|c|c|c|}
\hline \multirow[b]{3}{*}{ Characteristic } & \multicolumn{6}{|c|}{ Smoking status of spouse, 1959} & \multicolumn{2}{|c|}{1999 respondents } \\
\hline & \multirow[b]{2}{*}{ Never } & \multirow[b]{2}{*}{ Former } & \multicolumn{3}{|c|}{ Current (cigarettes/day) } & \multirow[b]{2}{*}{ Total } & \multirow[b]{2}{*}{1959 value } & \multirow[b]{2}{*}{1999 value } \\
\hline & & & 1-19 & $20-39$ & $\geq 40$ & & & \\
\hline No of participants in 1959 & 7458 & 624 & 905 & 587 & 45 & 9619 & & \\
\hline No of participants in 1999 & 498 & 59 & 69 & 51 & 4 & 681 & 681 & 681 \\
\hline Withdrawn as of $1972(\%)$ & $2.0(146)$ & $2.4(15)$ & $2.1(19)$ & $2.7(16)$ & $2.2(1)$ & $2.0(197)$ & & \\
\hline Lost to follow up as of $1999(\%)$ & $5.9(441)$ & $4.6(29)$ & $5.4(49)$ & $6.3(37)$ & $8.9(4)$ & $5.8(560)$ & & \\
\hline Unknown cause of death (\%) & $6.6(371)$ & $6.1(26)$ & $6.6(42)$ & $5.4(22)$ & $8.8(3)$ & $6.5(464)$ & & \\
\hline Widowed as of 1999 & 28.2 (1649) & 25.1 (124) & $31.9(231)$ & 38.1 (174) & $39.4(13)$ & $29.0(2191)$ & & \\
\hline Mean age (years) at enrolment & $56.5(7458)$ & $51.9(624)$ & $52.8(905)$ & $51.7(587)$ & $52.6(45)$ & 55.5 (9619) & $45.5(681)$ & $45.5(681)$ \\
\hline $\begin{array}{l}\text { White people (\%) } \\
\end{array}$ & $97.8(7292)$ & $98.6(615)$ & $98.0(887)$ & $98.1(577)$ & $100.0(45)$ & $97.9(9416)$ & $98.6(672)$ & \\
\hline Education $\geq 12$ years $(\%)$ & $67.3(5017)$ & $80.6(403)$ & $71.3(645)$ & $74.2(436)$ & $84.5(38)$ & 69.0 (6639) & $89.0(606)$ & $92.9(633)$ \\
\hline Mean height $(\mathrm{cm})$ & $175.8(7328)$ & $176.3(614)$ & $176.3(898)$ & $176.5(582)$ & $176.8(43)$ & $175.8(9465)$ & $177.0(681)$ & $175.3(681)$ \\
\hline Mean weight $(\mathrm{kg})$ & $78.9(7137)$ & $79.7(602)$ & $79.6(881)$ & $80.9(573)$ & $82.2(44)$ & 79.1 (9237) & $78.6(681)$ & $74.9(681)$ \\
\hline History of serious diseases (\%): & $13.8(965)$ & $10.0(59)$ & $11.9(102)$ & $11.9(65)$ & $12.5(5)$ & $13.3(1196)$ & $4.1(28)$ & \\
\hline Cancer & $5.0(369)$ & $4.7(29)$ & $5.5(50)$ & $4.6(27)$ & $2.2(1)$ & $5.0(476)$ & $2.9(20)$ & $39.9(272)$ \\
\hline Heart disease & $7.0(471)$ & $4.8(27)$ & $5.4(44)$ & $5.6(29)$ & $7.7(3)$ & $6.6(574)$ & $1.0(7)$ & \\
\hline Stroke & $1.8(125)$ & $0.5(3)$ & $1.0(8)$ & $1.7(9)$ & $2.6(1)$ & $1.7(146)$ & $0.2(1)$ & \\
\hline Sick at present time (\%) & $6.4(475)$ & $4.8(30)$ & $6.3(57)$ & $5.6(33)$ & $4.4(2)$ & $6.2(597)$ & $4.2(29)$ & $22.2(151)$ \\
\hline Professional occupation (\%) & $14.3(1068)$ & $14.9(93)$ & $11.1(100)$ & $10.5(62)$ & $17.8(8)$ & $13.8(1331)$ & $17.8(121)$ & \\
\hline Urban residence (\%) & $85.9(6404)$ & $90.7(566)$ & $88.7(803)$ & $90.0(529)$ & $88.9(40)$ & $86.7(8342)$ & $86.0(586)$ & \\
\hline Moderate or heavy exercise (\%) & $76.2(5683)$ & $70.2(438)$ & $72.5(656)$ & $71.1(418)$ & $57.8(26)$ & $75.0(7221)$ & $70.7(481)$ & $70.9(483)$ \\
\hline Eat green salads (mean days/week) & 4.8 (7201) & $4.9(617)$ & $5.0(887)$ & $5.0(573)$ & $4.9(45)$ & $4.8(9323)$ & $5.1(681)$ & $4.5(681)$ \\
\hline Eat fruits or drink fruit juice (mean days/week) & $6.0(7226)$ & $6.0(614)$ & $5.9(886)$ & $5.5(574)$ & $5.3(43)$ & 5.9 (9343) & $5.9(681)$ & $5.6(681)$ \\
\hline Often use vitamin pills (\%) & $38.1(2841)$ & $39.7(248)$ & $33.2(300)$ & $28.7(169)$ & $42.2(19)$ & $37.2(3577)$ & 34.0 (232) & 79.2 (539) \\
\hline
\end{tabular}

Some values do not agree with denominators due primarily to missing data. 
described in detail elsewhere..$^{15-17}$ A total of 1078894 adults from 25 states were enrolled on the basis of a detailed four page questionnaire. In 1961, 1963, 1965, and 1972, surviving cohort members completed brief questionnaires. The American Cancer Society ascertained the vital status and current address for most of

Table 3 Personal and lifestyle characteristics of female 1959 never smokers in California cancer prevention study (CPS I) cohort by smoking status of spouse

Smoking status of spouse, 1959

1999 respondents

\begin{tabular}{|c|c|c|c|c|c|c|c|c|c|}
\hline \multirow[b]{3}{*}{ Characteristic } & \multicolumn{7}{|c|}{ Smoking status of spouse, 1959} & \multicolumn{2}{|c|}{1999 respondents } \\
\hline & \multirow[b]{2}{*}{ Never } & \multirow[b]{2}{*}{ Former } & \multicolumn{4}{|c|}{ Current status* } & \multirow[b]{2}{*}{ Total } & \multirow[b]{2}{*}{1959 value } & \multirow[b]{2}{*}{1999 value } \\
\hline & & & Pipe or cigar & 1-19 & $20-39$ & $\geq \mathbf{4 0}$ & & & \\
\hline No of participants in 1959 & 7399 & 6858 & 2691 & 3219 & 4934 & 841 & 25942 & & \\
\hline No of participants in 1999 & 788 & 573 & 252 & 233 & 479 & 87 & 2412 & 2412 & 2412 \\
\hline Withdrawn as of $1972(\%)$ & $8.1(602)$ & $8.1(558)$ & $8.1(219)$ & $8.2(265)$ & $7.7(380)$ & $9.6(81)$ & $8.1(2105)$ & & \\
\hline Lost to follow up as of $1999(\%)$ & $9.8(722)$ & $9.8(669)$ & $9.7(260)$ & $10.1(324)$ & $10.4(513)$ & $10.8(91)$ & $9.9(2579)$ & & \\
\hline Unknown cause of death (\%) & $7.6(304)$ & $7.7(305)$ & $7.2(111)$ & $8.1(149)$ & $8.7(218)$ & $10.4(43)$ & $7.9(1130)$ & & \\
\hline Widowed as of $1999(\%)$ & $59.7(3464)$ & $65.2(3528)$ & $64.2(1368)$ & $69.6(1774)$ & 73.4 (2859) & $75.1(480)$ & $66.0(13473)$ & & \\
\hline Mean age (years) at enrolment & $53.1(7399)$ & $54.5(6858)$ & 54.4 (2691) & 53.7 (3219) & $50.9(4934)$ & 49.8 (841) & $53.1(25942)$ & $44.5(2412)$ & $44.5(2412)$ \\
\hline White people (\%) & $97.6(7225)$ & $98.5(6759)$ & $97.8(2631)$ & 95.9 (3088) & $97.9(4828)$ & 98.7 (831) & $97.8(25362)$ & $98.0(2364)$ & \\
\hline Education $\geq 12$ years $(\%)$ & $73.7(5452)$ & $68.2(4685)$ & $68.9(1853)$ & $65.6(2109)$ & $70.4(3476)$ & $77.2(650)$ & 70.2 (18 225) & $87.9(2120)$ & $93.0(2243)$ \\
\hline Mean height (cm) & $162.1(7232)$ & $161.8(6706)$ & $161.8(2640)$ & $161.5(3168)$ & $161.8(4846)$ & $162.3(822)$ & $161.8(25414)$ & $162.6(2412)$ & $161.3(2412)$ \\
\hline Mean weight $(\mathrm{kg})$ & $63.9(7085)$ & $63.8(6596)$ & $64.0(2581)$ & $63.5(3097)$ & $63.7(4777)$ & $63.64(824)$ & $63.8(24960)$ & $61.4(2412)$ & $62.3(2412)$ \\
\hline History of serious diseases (\%): & $11.8(834)$ & $12.8(857)$ & $11.3(293)$ & $10.2(315)$ & $10.1(483)$ & $10.2(85)$ & $11.4(2867)$ & $5.8(140)$ & \\
\hline Cancer & $5.8(427)$ & $6.7(465)$ & $5.8(156)$ & $5.2(167)$ & $5.9(293)$ & $7.2(61)$ & $6.0(1569)$ & $4.1(99)$ & $36.4(878)$ \\
\hline Heart disease & $5.1(347)$ & $5.1(330)$ & $4.7(117)$ & $4.2(123)$ & $3.4(154)$ & $2.9(23)$ & 4.5 (1 094) & $1.5(36)$ & \\
\hline Stroke & $0.9(60)$ & $1.0(62)$ & $0.8(20)$ & $0.8(25)$ & $0.8(36)$ & $0.1(1)$ & $0.9(204)$ & $0.2(5)$ & \\
\hline Sick at present time (\%) & $7.9(586)$ & $8.3(572)$ & $8.6(231)$ & $8.2(264)$ & $8.8(436)$ & $8.8(74)$ & $8.3(2163)$ & $6.4(154)$ & $19.7(475)$ \\
\hline Professional occupation (\%) & $14.6(1080)$ & $12.8(881)$ & $13.0(350)$ & $12.9(414)$ & $10.6(523)$ & $10.9(92)$ & $12.9(3340)$ & $17.4(420)$ & \\
\hline Urban residence (\%) & 85.8 (6349) & $86.4(5929)$ & $85.4(2298)$ & $86.2(2775)$ & 85.7 (4229) & $85.8(722)$ & 85.9 (22 302) & $84.7(2043)$ & \\
\hline Moderate or heavy exercise (\%) & $82.5(6097)$ & $82.5(5649)$ & $83.3(2242)$ & $82.8(2665)$ & $82.3(4058)$ & $81.0(681)$ & 82.6 (21 392) & $80.2(1934)$ & $65.5(1580)$ \\
\hline Eat green salads (mean days/week) & $5.1(7219)$ & $5.0(6701)$ & $5.1(2618)$ & $4.9(3122)$ & $5.1(4835)$ & $5.1(825)$ & $5.0(25320)$ & $5.4(2412)$ & $4.6(2412)$ \\
\hline $\begin{array}{l}\text { Eat fruits or drink fruit juice } \\
\text { (mean days/week) }\end{array}$ & $6.4(7227)$ & $6.3(6727)$ & $6.3(2621)$ & $6.1(3132)$ & $6.0(4846)$ & $6.0(826)$ & 6.2 (25 379) & $6.1(2412)$ & $5.6(2412)$ \\
\hline Often use vitamin pills (\%) & $40.4(2985)$ & $39.8(2728)$ & $38.2(1028)$ & $36.8(1183)$ & $35.3(1739)$ & $34.0(286)$ & 38.4 (9 949) & $38.3(924)$ & $81.2(1958)$ \\
\hline
\end{tabular}

${ }^{*}$ Cigar, pipe, or number of cigarettes consumed per day.

Some values do not agree with denominators due primarily to missing data.

Table 4 Percentage of cohort exposed to three measures of environmental tobacco smoke in 1999 by smoking status of spouse among 1959 never smokers who responded to 1999 follow up questionnaire. Subgroup of 1959 never smokers aged $\geq 50$ years at entry (born before 1910) also shown. Values are percentage (number) exposed to environmental tobacco smoke in 1999, except for data on marital status

\begin{tabular}{|c|c|c|c|c|c|c|c|}
\hline \multirow[b]{2}{*}{ Smoking status of spouse in 1959} & \multirow[b]{2}{*}{$\begin{array}{l}\text { Lived with } \\
\text { smoker }\end{array}$} & \multirow[b]{2}{*}{$\begin{array}{c}\text { Lived with } \\
\text { smoking spouse }\end{array}$} & \multicolumn{3}{|c|}{$\begin{array}{l}\text { Regular exposure to cigarette smoke from others } \\
\text { in work or daily life }\end{array}$} & \multicolumn{2}{|c|}{ Married only once as of 1999} \\
\hline & & & None & Light & $\begin{array}{l}\text { Moderate } \\
\text { or heavy }\end{array}$ & Current & Ever \\
\hline \multicolumn{8}{|l|}{1959 male never smokers } \\
\hline Never $(n=496)$ & $24.0(115)$ & $3.8(18)$ & $43.5(189)$ & $34.5(150)$ & $22.1(96)$ & $66.2(319)$ & $82.2(398)$ \\
\hline Former $(n=59)$ & $53.5(31)$ & $27.6(16)$ & $20.8(11)$ & $43.4(23)$ & $35.9(19)$ & $62.5(35)$ & $78.6(44)$ \\
\hline Current $(n=124)$ & $89.5(111)$ & $75.0(93)$ & $23.1(27)$ & $38.5(45)$ & $38.5(45)$ & $45.1(55)$ & $70.5(86)$ \\
\hline \multicolumn{8}{|l|}{1959 female never smokers } \\
\hline Never $(\mathrm{n}=788)$ & $32.5(253)$ & $3.7(29)$ & $61.7(398)$ & $24.3(157)$ & $14.0(90)$ & $39.5(306)$ & $89.2(686)$ \\
\hline Former $(n=573)$ & $73.6(421)$ & $55.2(316)$ & $41.3(196)$ & $26.5(126)$ & $32.2(153)$ & $32.6(187)$ & $84.0(474)$ \\
\hline \multicolumn{8}{|l|}{ Current: } \\
\hline Pipe or cigar $(\mathrm{n}=252)$ & $84.7(211)$ & $69.9(174)$ & $34.0(73)$ & $30.2(65)$ & $35.8(77)$ & $30.1(75)$ & $82.2(198)$ \\
\hline $1-19$ cigarettes/day $(n=233)$ & $93.0(212)$ & $83.3(190)$ & $25.5(53)$ & $28.8(60)$ & $45.7(95)$ & $22.0(50)$ & $80.4(180)$ \\
\hline 20-39 cigarettes/day $(n=479)$ & $98.7(467)$ & 91.1 (431) & $19.7(84)$ & $20.9(89)$ & $59.4(253)$ & $16.4(78)$ & $78.5(365)$ \\
\hline$\geq 40$ cigarettes/day $(n=87)$ & $98.8(84)$ & $83.5(71)$ & $16.2(13)$ & $12.5(10)$ & $71.3(57)$ & $14.8(13)$ & $73.9(65)$ \\
\hline Total of current smokers (1051) & $94.1(974)$ & $83.7(866)$ & $24.0(223)$ & $24.1(224)$ & $51.9(482)$ & $20.8(216)$ & $79.4(808)$ \\
\hline \multicolumn{8}{|c|}{1959 male never smokers aged $\geq 50$ years at enrolment } \\
\hline Never $(\mathrm{n}=94)$ & $11.5(10)$ & $2.3(2)$ & $58.2(46)$ & $24.1(19)$ & $17.7(12)$ & $47.8(43)$ & $80.0(72)$ \\
\hline Former $(n=11)$ & $36.4(4)$ & $18.2(2)$ & $50.0(5)$ & $20.0(2)$ & $30.0(3)$ & $45.5(5)$ & $90.9(10)$ \\
\hline Current $(\mathrm{n}=17)$ & $88.2(15)$ & $70.6(12)$ & $18.8(3)$ & $43.7(7)$ & $37.5(6)$ & $12.5(2)$ & $56.3(9)$ \\
\hline \multicolumn{8}{|c|}{1959 female never smokers aged $\geq \mathbf{5 0}$ years at enrolment } \\
\hline Never $(n=100)$ & $26.0(26)$ & $4.0(4)$ & $71.2(52)$ & $21.9(16)$ & $6.9(5)$ & $16.3(16)$ & $92.7(89)$ \\
\hline Former $(n=99)$ & $83.0(78)$ & $68.1(64)$ & $40.7(33)$ & $24.7(20)$ & $34.6(28)$ & $17.2(17)$ & $80.4(78)$ \\
\hline \multicolumn{8}{|l|}{ Current: } \\
\hline Pipe or cigar $(n=43)$ & $71.4(30)$ & $59.5(25)$ & $42.5(14)$ & $24.2(8)$ & $33.3(11)$ & $14.0(6)$ & $77.8(28)$ \\
\hline $1-19$ cigarettes/day $(n=29)$ & $96.3(26)$ & $85.2(23)$ & $20.0(5)$ & $28.0(7)$ & $52.0(13)$ & $6.9(2)$ & $84.6(22)$ \\
\hline 20-39 cigarettes/day $(n=75)$ & $97.1(72)$ & $87.7(67)$ & $14.8(7)$ & $21.9(13)$ & $63.3(43)$ & $7.9(6)$ & $81.7(58)$ \\
\hline$\geq 40$ cigarettes/day $(n=9)$ & $100.0(8)$ & $75.0(6)$ & 0 & 0 & $100.0(7)$ & $11.1(1)$ & $88.9(8)$ \\
\hline Total of current smokers $(n=156)$ & $90.7(136)$ & 80.7 (121) & $20.3(26)$ & $21.9(28)$ & $57.8(74)$ & $9.6(15)$ & $81.7(116)$ \\
\hline
\end{tabular}

Some values do not agree with denominators due primarily to missing data. 
Table 5 One measure of exposure to environmental tobacco smoke as of 1999 by smoking history of spouse in 1999 among 1959/1999 never smokers who responded to 1999 follow up questionnaire. Values are percentage (number) exposed to environmental tobacco smoke in 1999

\begin{tabular}{|c|c|c|c|c|}
\hline \multirow[b]{2}{*}{ Ever lived with a smoking spouse } & \multicolumn{4}{|c|}{ Regular exposure to cigarette smoke from others in work or daily life } \\
\hline & None & Light & Moderate & Heavy \\
\hline \multicolumn{5}{|l|}{$1959 / 1999$ male never smokers } \\
\hline No $(n=336)$ & $50.0(168)$ & $33.9(114)$ & $14.9(50)$ & $1.2(4)$ \\
\hline \multicolumn{5}{|l|}{ Yes: } \\
\hline No smoking nearby $(n=23)$ & $30.4(7)$ & $52.2(12)$ & $17.4(4)$ & 0 \\
\hline Exposed $1-19$ years $(n=17)$ & $17.6(3)$ & $29.4(5)$ & $41.2(7)$ & $11.8(2)$ \\
\hline Exposed $20-39$ years $(n=35)$ & $20.0(7)$ & $48.6(17)$ & $20.0(7)$ & $11.4(4)$ \\
\hline Exposed $40-80$ years $(n=33)$ & $6.1(2)$ & $27.3(9)$ & $57.5(19)$ & $9.1(3)$ \\
\hline \multicolumn{5}{|l|}{ 1959/1999 female never smokers } \\
\hline No $(n=570)$ & $76.7(437)$ & $16.1(92)$ & $5.3(30)$ & $1.9(11)$ \\
\hline \multicolumn{5}{|l|}{ Yes: } \\
\hline No smoking nearby $(\mathrm{n}=122)$ & $36.9(45)$ & $36.9(45)$ & $23.7(29)$ & $2.5(3)$ \\
\hline Exposed $1-19$ years $(n=162)$ & $29.0(47)$ & $38.9(63)$ & $27.2(44)$ & $4.9(8)$ \\
\hline Exposed $20-39$ years $(n=355)$ & $19.7(70)$ & $24.5(87)$ & $44.5(158)$ & $11.3(40)$ \\
\hline Exposed $40-80$ years $(n=323)$ & $14.1(46)$ & $20.5(66)$ & $44.3(143)$ & $21.1(68)$ \\
\hline \multicolumn{5}{|c|}{$1959 / 1999$ male never smokers aged $\geq 50$ years at enrolment } \\
\hline No $(n=70)$ & $62.9(44)$ & $24.3(17)$ & $11.4(8)$ & $1.4(1)$ \\
\hline \multicolumn{5}{|l|}{ Yes: } \\
\hline No smoking nearby $(\mathrm{n}=3)$ & $33.3(1)$ & $33.3(1)$ & $33.3(1)$ & 0 \\
\hline Exposed $1-19$ years $(n=2)$ & 0 & $50.0(1)$ & 0 & $50.0(1)$ \\
\hline Exposed $20-39$ years $(n=5)$ & $20.0(1)$ & $60.0(3)$ & $20.0(1)$ & 0 \\
\hline Exposed $40-80$ years $(n=5)$ & $20.0(1)$ & 0 & $60.0(3)$ & $20.0(1)$ \\
\hline \multicolumn{5}{|c|}{ 1959/1999 female never smokers aged $\geq 50$ years at enrolment } \\
\hline No $(n=73)$ & $89.0(65)$ & $9.6(7)$ & 0 & $1.4(1)$ \\
\hline \multicolumn{5}{|l|}{ Yes: } \\
\hline No smoking nearby $(n=20)$ & $25.0(5)$ & $60.0(12)$ & $10.0(2)$ & $5.0(1)$ \\
\hline Exposed $1-19$ years $(n=20)$ & $55.0(11)$ & $40.0(8)$ & $5.0(1)$ & 0 \\
\hline Exposed 20-39 years $(n=48)$ & $8.3(4)$ & $16.7(8)$ & $62.5(30)$ & $12.5(6)$ \\
\hline Exposed $40-80$ years $(n=66)$ & $15.2(10)$ & $18.2(12)$ & $45.4(30)$ & $21.2(14)$ \\
\hline
\end{tabular}

Some values do not agree with denominators due primarily to missing data.

the adults up to September 1972 and obtained death certificates for most of those known dead.

\section{Follow up}

Long term follow up was undertaken at the University of California at Los Angeles on all 118094 participants from California. This is described in detail elsewhere and summarised in table $1 .^{18}$ The participants were matched several times with the California death file and the social security death index on the basis of their name and other identifying variables. ${ }^{18} 19$ Overall, 79437 deaths were identified up to 31 December 1998, and the underlying cause was obtained from the California death file and death certificates for $93 \%$ (73 876) of these deaths.

Participants were also matched with information given on their California driver's licence, based primarily on name, date of birth, and height. We obtained the address given during the 1990s for 21897 participants who were not known as dead as of 1999 , and these participants were assumed to be alive in 1999. Of the remaining participants in the study's master database, 6845 were withdrawn from further follow up as of September 1972 because their complete name was not retained, and 9915 were lost to follow up as of 1999 because their vital status was unknown.

To assess the current status of surviving cohort members, in mid-1999 we sent out a two page questionnaire on smoking and lifestyle to those participants with an address for 1995 or later on their driver's licence. Overall, 2290 of 5275 men (43.4\%) and 4869 of 10738 women $(45.3 \%)$ completed the questionnaire. Responses to name, date of birth, and height on the questionnaire confirmed that over 99\% of the respondents had been accurately located.

The follow up period was from time of entry to the study (1 January to 31 March 1960) until death, withdrawal (date last known alive), or end of follow up (31 December 1998). The participants were aged 30-96 years at enrolment. We excluded the few person years of observation and the 36 deaths during 1959. The underlying cause of each death was assigned according to the international classification of diseases (seventh, eighth, or ninth revisions). Coronary heart disease was defined as 420 (ICD-7) during 1960-7, 410-4 (ICD-8) during 1968-78, and 410-4 (ICD-9) during 1979-98, lung cancer was defined as 162-3 (ICD-7), 162 (ICD-8), and 162 (ICD-9), and chronic obstructive pulmonary disease was defined as 241, 500-2, and 527.1 (ICD-7), 490-3 (ICD-8), and 490-6 (ICD-9). For the analysis of environmental tobacco smoke we selected the 35561 participants who had never smoked as of 1959 and who had a spouse in the study with known smoking habits.

\section{Statistical analysis}

The independent variable used for analysis was exposure to environmental tobacco smoke based on smoking status of the spouse in 1959, 1965, and 1972. Never smokers married to current or former smokers were compared with never smokers married to never smokers. The 1959 never smokers were defined as those who had never smoked any form of tobacco as of 1959. The 1965 never smokers were defined as 1959 never smokers who did not smoke cigarettes as of 1965. The 1972 never smokers were defined as 1959 
never smokers who did not smoke cigarettes as of 1965 and 1972. The 1959/1999 never smokers were defined as 1959 never smokers who had never smoked cigarettes as of 1999. Never smokers married to a current smoker were subdivided into categories according to the smoking status of their spouse: 1-9, 10-19, 20, $21-39, \geq 40$ cigarettes consumed per day for men and women, with the addition of pipe or cigar usage for women. Former smokers were considered as an additional category.

We calculated the age adjusted relative risk of death and $95 \%$ confidence interval as a function of smoking status of the spouse by using Cox proportional hazards regression. ${ }^{1820} \mathrm{~A}$ fully adjusted relative risk was calculated by using a model that included age and seven potential confounders at baseline: race (white, non-white), education level ( $<12,12,>12$ years), exercise (none or slight, moderate, heavy), body mass index $(<20,20-22.99,23-25.99,26-29.99, \geq 30)$, urbanisation (five population sizes), fruit or fruit juice intake (0-2, 3-4, 5-7 days a week), and health status (good, fair, poor, sick). Analyses were carried out for all participants and for healthy participants (those with no history of cancer, heart disease, or stroke at baseline). The relative risk was also calculated for current cigarette smokers (cigarettes only) as a function of number of cigarettes consumed per day for the entire cohort. ${ }^{18}$ For reference, the age adjusted death rate has been calculated by cause of death for all never smokers. $^{18}$

\section{Results}

The personal and lifestyle characteristics and follow up status for 1959 never smokers were relatively independent of their spouse's smoking status (tables 2 and 3). Also, the baseline characteristics of the 1999 respondents in 1959 were similar to those for all participants in 1959, except for a younger age at enrolment. Although heavily censored by age, the 1999 respondents seemed reasonably representative of survivors. Race, education, exercise, height, weight, and fruit intake had also remained largely unchanged among the 1999 respondents since 1959. The proportion of participants who had withdrawn as of 1972, were lost as of 1999, or had an unknown cause of death was not related to the smoking status of spouses. However, widowhood (widowed as of 1999) increased substantially with the level of smoking in the spouse.

The smoking status of spouses as of 1959 was related to three self reported measures of exposure to environmental tobacco smoke as of 1999 (table 4). Particularly for women, there was a clear relation between smoking status of spouses as of 1959 and self reported measures in 1999 of having lived with a smoker, having lived with a smoking spouse, and a positive answer to the question "In your work or daily life, are (were) you regularly exposed to cigarette smoke from others?" Also, the percentage of participants currently married as of 1999 declined substantially with the smoking status of the spouse, owing to increased widowhood.

Table 6 Percentage of current smokers by cigarettes consumed per day as of 1965, 1972, and 1999, and former smokers by year of cessation as of 1999 among 1959 never smokers by smoking status of spouse. Values are percentages (numbers) of cigarette smokers

\begin{tabular}{|c|c|c|c|c|c|c|c|}
\hline \multirow[b]{2}{*}{1959 spousal smoking } & \multicolumn{2}{|c|}{$\begin{array}{l}\text { Current smoking as of } 1965 \\
\text { (cigarettes/day) }\end{array}$} & \multicolumn{2}{|c|}{$\begin{array}{l}\text { Current smoking as of } 1972 \\
\text { (cigarettes/day) }\end{array}$} & \multicolumn{3}{|c|}{ Cigarette smoking as of 1999} \\
\hline & $1-9$ & $\geq 10$ & $1-9$ & $\geq 10$ & Current & $\begin{array}{c}\text { Former } \\
\text { (quit }<1960 \text { ) }\end{array}$ & $\begin{array}{c}\text { Former } \\
\text { (quit } \geq 1960 \text { ) }\end{array}$ \\
\hline \multicolumn{8}{|l|}{1959 male never smokers } \\
\hline & \multicolumn{2}{|c|}{$(n=8$ 602) } & \multicolumn{2}{|c|}{$(n=5479)$} & \multicolumn{3}{|c|}{$(\mathrm{n}=679)$} \\
\hline Never & $0.3(16)$ & $0.8(36)$ & $0.2(5)$ & $0.2(8)$ & $0.2(1)$ & $5.2(24)$ & $0.7(3)$ \\
\hline Former & $0.4(2)$ & $1.2(6)$ & 0 & $0.8(2)$ & 0 & $15.3(6)$ & 0 \\
\hline Current & $0.7(8)$ & $2.0(25)$ & $0.3(3)$ & $0.5(4)$ & 0 & $6.5(8)$ & $1.6(2)$ \\
\hline \multicolumn{8}{|c|}{1959 female never smokers } \\
\hline & \multicolumn{2}{|c|}{$(n=24112)$} & \multicolumn{2}{|c|}{$(\mathrm{n}=16237)$} & \multicolumn{3}{|c|}{$(\mathrm{n}=2412)$} \\
\hline Never & $0.3(16)$ & $0.4(19)$ & $0.3(9)$ & $0.4(12)$ & $0.3(2)$ & $2.8(16)$ & $1.4(8)$ \\
\hline Former & $0.5(24)$ & $0.4(25)$ & $0.2(9)$ & $0.3(9)$ & $0.2(1)$ & $5.0(22)$ & $0.9(4)$ \\
\hline \multicolumn{8}{|l|}{ Current: } \\
\hline Pipe or cigar & $0.6(15)$ & $0.4(9)$ & $0.6(7)$ & $0.4(4)$ & $0.4(1)$ & $1.8(3)$ & $1.8(3)$ \\
\hline $1-19$ cigarettes/day & $0.8(21)$ & $0.9(22)$ & $0.6(9)$ & $0.5(7)$ & 0 & $1.7(4)$ & $2.2(5)$ \\
\hline 20-39 cigarettes/day & $1.0(41)$ & $1.2(52)$ & $0.5(13)$ & $0.6(15)$ & $0.2(1)$ & $1.4(6)$ & $1.7(7)$ \\
\hline$\geq 40$ cigarettes/day & $1.4(10)$ & $1.6(11)$ & $0.6(3)$ & $0.2(1)$ & $1.1(1)$ & $6.4(5)$ & $3.9(3)$ \\
\hline Total of current smokers & $0.9(87)$ & $0.9(94)$ & $0.6(32)$ & $0.5(27)$ & $0.3(3)$ & $2.0(18)$ & $2.0(18)$ \\
\hline \multicolumn{8}{|c|}{1959 male never smokers aged $\geq \mathbf{5 0}$ years at enrolment } \\
\hline & \multicolumn{2}{|c|}{$(n=5521)$} & \multicolumn{2}{|c|}{$(n=3306)$} & \multicolumn{3}{|c|}{$(\mathrm{n}=122)$} \\
\hline Never & $0.3(10)$ & $0.8(23)$ & $0.1(1)$ & $0.2(4)$ & 0 & $5.3(5)$ & 0 \\
\hline Former & 0 & $1.4(4)$ & 0 & 0 & 0 & $9.1(1)$ & 0 \\
\hline Current & $0.6(4)$ & $2.5(16)$ & 0 & $0.6(3)$ & 0 & $11.8(2)$ & 0 \\
\hline \multicolumn{8}{|c|}{1959 female never smokers aged $\geq \mathbf{5 0}$ years at enrolment } \\
\hline & \multicolumn{2}{|c|}{$(n=14014)$} & \multicolumn{2}{|c|}{$(n=8957)$} & \multicolumn{3}{|c|}{$(n=355)$} \\
\hline Never & $0.2(6)$ & $0.3(6)$ & $0.3(4)$ & $0.3(4)$ & 0 & $1.0(1)$ & 0 \\
\hline Former & $0.1(4)$ & $0.5(13)$ & $0.2(4)$ & 0 & 0 & $7.1(7)$ & 0 \\
\hline \multicolumn{8}{|l|}{ Current: } \\
\hline Pipe or cigar & $0.2(3)$ & $0.2(4)$ & $0.4(1)$ & 0 & 0 & $2.3(1)$ & 0 \\
\hline 1-19 cigarettes/day & $0.4(5)$ & $0.8(12)$ & $0.3(2)$ & $0.6(4)$ & 0 & $3.4(1)$ & 0 \\
\hline 20-39 cigarettes/day & $0.7(14)$ & $0.9(20)$ & $0.5(5)$ & $0.5(4)$ & $1.3(1)$ & 0 & $2.7(2)$ \\
\hline$\geq 40$ cigarettes/day & $0.6(2)$ & $1.6(5)$ & $0.8(2)$ & 0 & 0 & 0 & 0 \\
\hline Total of current smokers & $0.4(24)$ & $0.8(41)$ & $0.4(10)$ & $0.4(8)$ & $0.6(1)$ & $1.3(2)$ & $1.3(2)$ \\
\hline
\end{tabular}

Some values do not agree with denominators due primarily to missing data. 
Table 7 Level of smoking in spouse and deaths from selected causes among male never smokers in California cancer prevention study (CPS I) cohort, as of 1959 and 1972. Relative risk (95\% confidence interval) comparing individuals with each level of exposure to those without exposure. Proportional hazards linear models adjusted for age and for age and seven confounders. For reference, 1960-98 death rate in deaths per 1000 person years adjusted to 1960 US population for attained ages $35-84$ is given ${ }^{18}$

\begin{tabular}{|c|c|c|c|c|c|c|c|}
\hline \multirow[b]{2}{*}{$\begin{array}{l}\text { Smoking in spouse } \\
\text { and cause of death }\end{array}$} & \multicolumn{3}{|c|}{ All 1959 participants, followed $1960-98$} & \multicolumn{2}{|c|}{$\begin{array}{l}1959 \text { participants aged } \geq 50, \\
\text { followed } 1960-98\end{array}$} & \multicolumn{2}{|c|}{$\begin{array}{l}\text { Participants defined in 1972, } \\
\text { followed } 1973-98\end{array}$} \\
\hline & $\begin{array}{l}\text { No of deaths/No of } \\
\text { participants }\end{array}$ & $\begin{array}{l}\text { Age adjusted } \\
\text { relative risk } \\
(95 \% \mathrm{Cl})\end{array}$ & $\begin{array}{l}\text { Fully adjusted } \\
\text { relative risk } \\
(95 \% \mathrm{Cl})\end{array}$ & $\begin{array}{l}\text { No of deaths/No of } \\
\text { participants }\end{array}$ & $\begin{array}{l}\text { Age adjusted } \\
\text { relative risk } \\
(95 \% \mathrm{Cl})\end{array}$ & $\begin{array}{l}\text { No of deaths/No of } \\
\text { participants }\end{array}$ & $\begin{array}{l}\text { Age adjusted } \\
\text { relative risk } \\
(95 \% \mathrm{Cl})\end{array}$ \\
\hline \multicolumn{8}{|c|}{ Coronary heart disease (death rate $3.05 / 1000$ ) } \\
\hline Never $(1)^{\star}$ & $1860 / 7458$ & 1.00 & 1.00 & $1534 / 5201$ & 1.00 & $806 / 3404$ & 1.00 \\
\hline Former $(2)^{*}$ & $126 / 624$ & 0.94 (0.78 to 1.12$)$ & 0.94 (0.77 to 1.14$)$ & $83 / 323$ & 0.93 (0.74 to 1.16$)$ & $114 / 573$ & $0.94(0.77$ to 1.14$)$ \\
\hline \multicolumn{8}{|c|}{ Current (cigarettes/day): } \\
\hline $1-9(3)^{*}$ & $81 / 392$ & 0.97 (0.78 to 1.21$)$ & 0.98 (0.78 to 1.24$)$ & $59 / 230$ & $1.00(0.77$ to 1.30$)$ & $20 / 89$ & $1.32(0.84$ to 2.06$)$ \\
\hline $10-19(4)^{\star}$ & $99 / 513$ & 0.86 (0.70 to 1.05$)$ & 0.82 (0.66 to 1.02$)$ & $73 / 282$ & 0.91 (0.72 to 1.15$)$ & $33 / 153$ & $1.02(0.72$ to 1.45$)$ \\
\hline $20(5)^{\star}$ & $81 / 458$ & $0.92(0.74$ to 1.15$)$ & 0.89 (0.70 to 1.13$)$ & $58 / 245$ & $1.02(0.78$ to 1.32$)$ & $35 / 189$ & $0.94(0.67$ to 1.32$)$ \\
\hline $21-39(6)^{\star}$ & $27 / 129$ & 1.16 (0.79 to 1.69$)$ & $1.13(0.76$ to 1.68$)$ & $19 / 62$ & 1.30 (0.82 to 2.04$)$ & $14 / 58$ & $1.20(0.70$ to 2.03$)$ \\
\hline$\geq 40(7)^{\star}$ & $13 / 45$ & 1.29 (0.75 to 2.22$)$ & $1.24(0.70$ to 2.19$)$ & $9 / 26$ & 1.25 (0.65 to 2.41$)$ & $4 / 36$ & $0.65(0.24$ to 1.73$)$ \\
\hline $\begin{array}{l}\text { Total of current } \\
\text { smokers }\end{array}$ & $301 / 1537$ & 0.94 (0.83 to 1.07 ) & 0.92 (0.80 to 1.05$)$ & $218 / 845$ & 1.00 (0.87 to 1.15$)$ & $106 / 525$ & $1.04(0.85$ to 1.27$)$ \\
\hline Ever & $427 / 2161$ & 0.94 (0.85 to 1.05$)$ & 0.93 (0.83 to 1.04$)$ & $301 / 1168$ & $0.98(0.86$ to 1.11$)$ & $220 / 1098$ & $0.99(0.85$ to 1.15$)$ \\
\hline 7 level index & $2287 / 9619$ & 0.99 (0.95 to 1.02$)$ & 0.98 (0.94 to 1.02$)$ & $1835 / 6369$ & $1.00(0.96$ to 1.05$)$ & $1026 / 4502$ & $1.00(0.95$ to 1.05$)$ \\
\hline \multicolumn{8}{|c|}{ Lung cancer (death rate $0.11 / 1000$ ) } \\
\hline Never & 65 & 1.00 & 1.00 & 50 & 1.00 & 27 & 1.00 \\
\hline Former & 5 & 0.92 (0.37 to 2.30$)$ & 0.82 (0.29 to 2.26$)$ & 3 & 0.89 (0.28 to 2.88$)$ & 3 & $0.63(0.19$ to 2.09$)$ \\
\hline Current & 9 & 0.69 (0.34 to 1.39$)$ & 0.57 (0.26 to 1.26$)$ & 5 & $0.60(0.24$ to 1.52$)$ & 1 & $0.23(0.03$ to 1.68$)$ \\
\hline$\overline{\text { Ever }}$ & 14 & $0.75(0.42$ to 1.35$)$ & 0.63 (0.33 to 1.22$)$ & 8 & $0.69(0.32$ to 1.46$)$ & 4 & $0.43(0.15$ to 1.24$)$ \\
\hline 7 level index & 79 & 0.94 (0.77 to 1.14$)$ & 0.88 (0.70 to 1.10$)$ & 58 & 0.91 (0.71 to 1.17 ) & 31 & $0.68(0.41$ to 1.13$)$ \\
\hline \multicolumn{8}{|c|}{ Chronic obstructive pulmonary disease (death rate $0.12 / 1000$ ) } \\
\hline Never & 69 & 1.00 & 1.00 & 59 & 1.00 & 30 & 1.00 \\
\hline Former & 5 & 0.95 (0.38 to 2.37$)$ & $1.00(0.40$ to 2.50$)$ & 4 & 1.09 (0.40 to 3.02$)$ & 4 & $0.88(0.31$ to 2.50$)$ \\
\hline Current & 17 & $1.40(0.82$ to 2.40$)$ & 1.28 (0.72 to 2.27$)$ & 13 & 1.51 (0.82 to 2.78$)$ & 7 & $1.80(0.78$ to 4.17$)$ \\
\hline Ever & 22 & 1.27 (0.78 to 2.08$)$ & $1.20(0.72$ to 2.00$)$ & 17 & $1.39(0.81$ to 2.41$)$ & 11 & $1.29(0.64$ to 2.61$)$ \\
\hline 7 level index & 91 & $1.06(0.91$ to 1.25$)$ & 1.05 (0.88 to 1.24$)$ & 76 & $1.09(0.91$ to 1.30$)$ & 41 & $1.08(0.86$ to 1.38$)$ \\
\hline
\end{tabular}

*Values in parentheses are index level of environmental tobacco smoke.

Smoking history of the spouse as assessed in 1999 was strongly related to exposure to environmental tobacco smoke as of 1999 for both men and women (table 5).

Misclassification of exposure and smoking status

Although there was substantial misclassification of environmental tobacco smoke exposure status from 1959 to 1999 , it was less for those never smokers aged 50 or over at enrolment (see table 4), never smokers defined in 1972 (data not shown), and never smokers defined in 1999 (see table 5). Misclassification of exposure status produces a measured relative risk that is closer to 1.0 than the true relative risk. ${ }^{813}$ The extent of misclassification from 1959 to 1999 could not obscure a true association with a relative risk of about 1.3 , if it exists, among women, but it could largely obscure this association among men. However, this level of misclassification, which is based on the changes that occurred over 40 years among the younger than average 1999 respondents, exaggerates the true level of misclassification that occurred among the cohort as a whole, particularly during short follow up periods.

Essentially all 1959 never smokers remained never smokers on the basis of smoking status reported in 1965, 1972, and 1999 (table 6). Of those who reported a history of smoking in 1999, most had smoked no more than 10 cigarettes per day for a few years, and most had quit smoking before 1960. This indicates only a small degree of misclassification of smoking status. Some bias exists in the misclassification of smoking status among the 1959 never smokers, because the percentage who smoked in the 1965 and 1972 surveys was greatest among those with the highest levels of smoking in spouses. This bias produces a measured relative risk that is greater than the true relative risk, but by a negligible amount for this level of bias. ${ }^{8}{ }^{13}$

Effect of exposure to environmental tobacco smoke Exposure to environmental tobacco smoke was not significantly associated with the death rate for coronary heart disease, lung cancer, or chronic obstructive pulmonary disease in men or women (tables 7 and 8). This was true for all 1959 never smokers and 1959 never smokers aged 50 or over at enrolment followed during 1960-98 and for 1972 never smokers followed during 1973-98. The relative risks were slightly reduced after adjustment for seven confounders. Results were essentially unchanged among the healthy participants only (data not shown). The relative risks were consistent with 1.0 for virtually every level of exposure to environmental tobacco smoke, current or former. Only the relative risks for chronic obstructive pulmonary disease suggested an association. An environmental tobacco smoke index based on seven or eight levels of smoking in a spouse yielded a relative risk of about 1.0 for each level of change and no suggestion of a dose-response trend.

In addition, analyses for coronary heart disease were performed for three short follow up periods with presumably smaller misclassification errors. All relative risks for coronary heart disease were consistent with 1.0 for the follow up periods of 1960-5, 1966-72, and 1973-85 for never smokers defined as of 1959, 1965, and 1972 (table 9). In particular, the relative risk for current smoking in a spouse was not increased, and 
there were no trends based on the environmental tobacco smoke index.

As expected, there was a strong, positive doseresponse relation between active cigarette smoking and deaths from coronary heart disease, lung cancer, and chronic obstructive pulmonary disease during 1960-98 (table $10^{10}$ ). These relative risks were consistent with those for the full CPS I cohort until $1972 .{ }^{15}{ }^{17}$ As it is generally considered that exposure to environmental tobacco smoke is roughly equivalent to smoking one cigarette per day, ${ }^{4}$ we extrapolated the relative risk due to exposure to environmental tobacco smoke from the relative risks for smoking 1-9 cigarettes per day. These extrapolated relative risks were about 1.03 for coronary heart disease and about 1.20 for lung cancer and chronic obstructive pulmonary disease. Based on these findings, exposure to environmental tobacco smoke could not plausibly cause a 30\% increase in risk of coronary heart disease in this cohort, although a $20 \%$ increase in risk of lung cancer and chronic obstructive pulmonary disease could not be ruled out.

\section{Discussion}

On the basis of our findings from the long term follow up of the California cohort of the cancer prevention study (CPS I), the association between exposure to environmental tobacco smoke and coronary heart dis- ease and lung cancer may be considerably weaker than generally believed. Although participants in CPS I are not a representative sample of the US population, never smokers in this cohort had a total death rate that was close to that of US white never smokers. ${ }^{21}$ Furthermore, the relative risks were based on comparisons within the cohort and should be valid. Although the participants' total exposure to smoking in a spouse was affected by the substantial extent of smoking cessation since $1959,{ }^{18}$ this did not affect the relative comparisons. Also, the relative risks during short follow up periods, with limited cessation, were similar to the long term risks.

\section{Strengths of study}

CPS I has several important strengths: long established value as a prospective epidemiological study, large size, extensive baseline data on smoking and potential confounders, extensive follow up data, and excellent long term follow up. None of the other cohort studies on environmental tobacco smoke has more strengths, and none has presented as many detailed results. Considering these strengths as a whole, the CPS I cohort is one of the most valuable samples for studying the relation between environmental tobacco smoke and mortality.

Concern has been expressed that smoking status of the spouse as of 1959 does not accurately reflect total exposure to environmental tobacco smoke because there was so much exposure to non-residential

Table 8 Level of smoking in spouse and deaths from selected causes among female never smokers in California cancer prevention study (CPS I) cohort, as of 1959 and 1972. For reference, 1960-98 death rate in deaths per 1000 person years adjusted to 1960 US population for attained ages $35-84$ is given ${ }^{18}$

\begin{tabular}{|c|c|c|c|c|c|c|c|}
\hline \multirow[b]{2}{*}{$\begin{array}{l}\text { Smoking in spouse } \\
\text { and cause of death }\end{array}$} & \multicolumn{3}{|c|}{ All 1959 participants, followed $1960-98$} & \multicolumn{2}{|c|}{$\begin{array}{l}1959 \text { participants aged } \geq 50, \\
\text { followed } 1960-98\end{array}$} & \multicolumn{2}{|c|}{$\begin{array}{l}\text { Participants defined in 1972, } \\
\text { followed } 1973-98\end{array}$} \\
\hline & $\begin{array}{l}\text { No of deaths/No of } \\
\text { participants }\end{array}$ & $\begin{array}{l}\text { Age adjusted relative } \\
\text { risk }(95 \% \mathrm{CI})\end{array}$ & $\begin{array}{l}\text { Fully adjusted } \\
\text { relative risk } \\
(95 \% \mathrm{Cl})\end{array}$ & $\begin{array}{l}\text { No of deaths/No of } \\
\text { participants }\end{array}$ & $\begin{array}{l}\text { Age adjusted relative } \\
\text { risk }(95 \% \mathrm{CI})\end{array}$ & $\begin{array}{l}\text { No of deaths/No of } \\
\text { participants }\end{array}$ & $\begin{array}{l}\text { Age adjusted relative } \\
\text { risk }(95 \% \mathrm{Cl})\end{array}$ \\
\hline \multicolumn{8}{|c|}{ Coronary heart disease (death rate $1.65 / 1000$ ) } \\
\hline Never $(1)^{*}$ & $1053 / 7399$ & 1.00 & 1.00 & $891 / 4230$ & 1.00 & $428 / 3090$ & 1.00 \\
\hline Former $(2)^{*}$ & $1059 / 6858$ & $1.02(0.93$ to 1.11$)$ & $1.03(0.94$ to 1.13$)$ & $909 / 4424$ & 0.98 (0.89 to 1.08$)$ & $772 / 5079$ & $1.03(0.92$ to 1.16$)$ \\
\hline \multicolumn{8}{|l|}{ Current: } \\
\hline Pipe or cigar $(3)^{*}$ & $389 / 2691$ & $0.99(0.88$ to 1.11$)$ & $0.97(0.86$ to 1.10$)$ & $162 / 1735$ & $0.97(0.86$ to 1.10$)$ & $24 / 173$ & 0.99 (0.66 to 1.49$)$ \\
\hline $\begin{array}{l}\text { 1-9 cigarettes/day } \\
(4)^{\star}\end{array}$ & $183 / 1102$ & $1.13(0.97$ to 1.33$)$ & $1.03(0.86$ to 1.23$)$ & $162 / 719$ & $1.15(0.97$ to 1.36$)$ & $24 / 200$ & $0.89(0.59$ to 1.34$)$ \\
\hline $\begin{array}{l}10-19 \\
\text { cigarettes/day }(5)^{*}\end{array}$ & $310 / 2117$ & $1.03(0.91$ to 1.17$)$ & 0.99 (0.86 to 1.14$)$ & $272 / 1301$ & $1.03(0.90$ to 1.18$)$ & $42 / 344$ & $0.90(0.66$ to 1.24$)$ \\
\hline $\begin{array}{l}20 \text { cigarettes/day } \\
(6)^{\star}\end{array}$ & $412 / 3288$ & $1.04(0.92$ to 1.16$)$ & $1.02(0.90$ to 1.16$)$ & $309 / 1735$ & $0.96(0.84$ to 1.10$)$ & $89 / 616$ & $1.30(1.04$ to 1.64$)$ \\
\hline $\begin{array}{l}21-39 \\
\text { cigarettes/day }(7)^{*}\end{array}$ & $167 / 1646$ & 0.95 (0.80 to 1.12$)$ & 0.88 (0.74 to 1.06$)$ & $127 / 792$ & 0.95 (0.79 to 1.15$)$ & $25 / 239$ & $1.14(0.76$ to 1.71$)$ \\
\hline $\begin{array}{l}\geq 40 \text { cigarettes/day } \\
(8)^{\star}\end{array}$ & $72 / 841$ & $0.83(0.65$ to 1.06$)$ & $0.80(0.62$ to 1.03$)$ & $49 / 399$ & $0.74(0.55$ to 0.98$)$ & $20 / 211$ & $0.89(0.57$ to 1.40$)$ \\
\hline $\begin{array}{l}\text { Total of current } \\
\text { smokers }\end{array}$ & $1533 / 11685$ & $1.01(0.93$ to 1.09$)$ & 0.97 (0.89 to 1.06$)$ & $1258 / 6681$ & $0.98(0.90$ to 1.07$)$ & $224 / 1783$ & $1.06(0.90$ to 1.25$)$ \\
\hline Ever & $2592 / 18543$ & 1.01 (0.94 to 1.08$)$ & $0.99(0.92$ to 1.08$)$ & $2167 / 11105$ & $0.98(0.91$ to 1.06$)$ & $996 / 6862$ & $1.04(0.93$ to 1.16$)$ \\
\hline 8 level index & $3645 / 25942$ & $1.00(0.98$ to 1.01$)$ & $0.99(0.97$ to 1.00$)$ & $3058 / 15335$ & 0.99 (0.97 to 1.01$)$ & $1424 / 9952$ & $1.02(0.98$ to 1.05$)$ \\
\hline \multicolumn{8}{|c|}{ Lung cancer (death rate $0.08 / 1000$ ) } \\
\hline Never & 51 & 1.00 & 1.00 & 31 & 1.00 & 25 & 1.00 \\
\hline Former & 51 & $1.08(0.73$ to 1.60$)$ & 1.04 (0.69 to 1.57$)$ & 33 & $1.02(0.62$ to 1.66$)$ & 39 & $0.92(0.56$ to 1.53$)$ \\
\hline Current & 75 & $0.93(0.65$ to 1.33$)$ & $0.88(0.60$ to 1.28$)$ & 44 & $0.86(0.54$ to 1.36$)$ & 14 & 1.00 (0.52 to 1.92$)$ \\
\hline Ever & 126 & 0.99 (0.72 to 1.37$)$ & 0.94 (0.66 to 1.33$)$ & 77 & 0.93 (0.61 to 1.41$)$ & 53 & 0.95 (0.59 to 1.53$)$ \\
\hline 8 level index & 177 & $0.97(0.91$ to 1.04$)$ & 0.97 (0.90 to 1.05$)$ & 108 & $0.98(0.89$ to 1.07$)$ & 78 & $0.99(0.87$ to 1.13$)$ \\
\hline \multicolumn{8}{|c|}{ Chronic obstructive pulmonary disease (death rate $0.08 / 1000$ ) } \\
\hline Never & 45 & 1.00 & 1.00 & 35 & 1.00 & 21 & 1.00 \\
\hline Former & 50 & $1.17(0.78$ to 1.75$)$ & $1.24(0.80$ to 1.93$)$ & 37 & $1.01(0.64$ to 1.60$)$ & 36 & $1.00(0.59$ to 1.72$)$ \\
\hline Current & 78 & $1.11(0.77$ to 1.60$)$ & $1.12(0.74$ to 1.69$)$ & 54 & 0.94 (0.61 to 1.44$)$ & 18 & $1.57(0.84$ to 2.96$)$ \\
\hline Ever & 128 & $1.13(0.80$ to 1.58$)$ & $1.16(0.80$ to 1.70$)$ & 91 & $0.97(0.66$ to 1.44$)$ & 54 & $1.14(0.69$ to 1.89$)$ \\
\hline 8 level index & 173 & $0.99(0.92$ to 1.06$)$ & 0.98 (0.91 to 1.06$)$ & 126 & $0.97(0.89$ to 1.06$)$ & 75 & $1.06(0.94$ to 1.20$)$ \\
\hline
\end{tabular}

${ }^{*}$ Values in parentheses are index level of environmental tobacco smoke. 
Table 9 Level of smoking in spouse and deaths from coronary heart disease among never smokers in California cancer prevention study (CPS I) cohort, as of 1959, 1965, and 1972

\begin{tabular}{|c|c|c|c|c|c|c|}
\hline \multirow[b]{2}{*}{ Smoking in spouse } & \multicolumn{2}{|c|}{$1960-5$} & \multicolumn{2}{|c|}{$1966-72$} & \multicolumn{2}{|c|}{$1973-85$} \\
\hline & $\begin{array}{l}\text { No of deaths/No of } \\
\text { participants }\end{array}$ & $\begin{array}{l}\text { Age adjusted } \\
\text { relative risk } \\
(95 \% \mathrm{Cl})\end{array}$ & $\begin{array}{l}\text { No of deaths/No of } \\
\text { participants }\end{array}$ & $\begin{array}{l}\text { Age adjusted } \\
\text { relative risk } \\
(95 \% \mathrm{Cl})\end{array}$ & $\begin{array}{l}\text { No of deaths/No of } \\
\text { participants }\end{array}$ & $\begin{array}{c}\text { Age adjusted } \\
\text { relative risk } \\
(95 \% \mathrm{Cl})\end{array}$ \\
\hline \multicolumn{7}{|l|}{ Males*: } \\
\hline Never & $224 / 7458$ & 1.00 & $304 / 6762$ & 1.00 & $769 / 5300$ & 1.00 \\
\hline Former & $7 / 624$ & 0.64 (0.30 to 1.35$)$ & $19 / 581$ & 1.07 (0.67 to 1.71$)$ & $47 / 490$ & 0.95 (0.71 to 1.28$)$ \\
\hline Current & $30 / 1537$ & 1.07 (0.72 to 1.57$)$ & $36 / 1429$ & 0.85 (0.60 to 1.20$)$ & $120 / 1185$ & 0.97 (0.80 to 1.18$)$ \\
\hline Ever & $37 / 2161$ & 0.94 (0.66 to 1.34$)$ & $55 / 2010$ & 0.91 (0.68 to 1.21 ) & $167 / 1675$ & 0.97 (0.82 to 1.15$)$ \\
\hline 7 level indext & $261 / 9619$ & 1.02 (0.91 to 1.15$)$ & $359 / 8772$ & 0.95 (0.86 to 1.05$)$ & $936 / 6975$ & 1.01 (0.95 to 1.06$)$ \\
\hline \multicolumn{7}{|l|}{ Females*: } \\
\hline Never & $49 / 7399$ & 1.00 & $124 / 7008$ & 1.00 & $408 / 5343$ & 1.00 \\
\hline Former & $63 / 6858$ & 1.26 (0.87 to 1.84$)$ & $102 / 6432$ & 0.83 (0.64 to 1.08 ) & $410 / 4896$ & 1.01 (0.88 to 1.15$)$ \\
\hline Current & $61 / 11685$ & 1.10 (0.75 to 1.62$)$ & $141 / 11002$ & 0.87 (0.68 to 1.11$)$ & $565 / 8433$ & $1.02(0.90$ to 1.16$)$ \\
\hline Ever & $124 / 18543$ & $1.16(0.83$ to 1.61$)$ & $243 / 17434$ & 0.85 (0.68 to 1.06$)$ & $975 / 13323$ & $1.02(0.90$ to 1.14$)$ \\
\hline 8 level indext & $173 / 25942$ & 1.01 (0.93 to 1.10$)$ & $367 / 24442$ & 0.98 (0.92 to 1.03$)$ & $1393 / 18666$ & 1.00 (0.98 to 1.03$)$ \\
\hline \multicolumn{7}{|l|}{ Malesł: } \\
\hline Never & & & $271 / 6173$ & 1.00 & $453 / 3404$ & 1.00 \\
\hline Former & & & $20 / 726$ & 0.87 (0.55 to 1.37 ) & $56 / 573$ & 0.93 (0.70 to 1.23$)$ \\
\hline Current & & & $26 / 1053$ & 0.79 (0.53 to 1.19$)$ & $48 / 525$ & 1.00 (0.74 to 1.35$)$ \\
\hline Ever & & & $46 / 1779$ & 0.82 (0.60 to 1.13$)$ & $104 / 1098$ & 0.96 (0.77 to 1.20$)$ \\
\hline 7 level index & & & $317 / 8265$ & 0.97 (0.87 to 1.08$)$ & $557 / 4502$ & 1.00 (0.93 to 1.09$)$ \\
\hline Undefined after 1959 & & & $42 / 726$ & & $379 / 2473$ & \\
\hline \multicolumn{7}{|l|}{ Femalesł: } \\
\hline Never & & & $92 / 6138$ & 1.00 & $180 / 3090$ & 1.00 \\
\hline Former & & & $112 / 9042$ & 0.81 (0.62 to 1.07$)$ & $287 / 5079$ & 0.92 (0.76 to 1.11$)$ \\
\hline Current & & & $62 / 5660$ & 0.98 (0.70 to 1.36$)$ & $81 / 1783$ & 1.02 (0.78 to 1.33$)$ \\
\hline Ever & & & $174 / 14702$ & 0.86 (0.67 to 1.11$)$ & $368 / 6862$ & 0.94 (0.79 to 1.13$)$ \\
\hline 8 level indext & & & $266 / 20840$ & 1.00 (0.94 to 1.07$)$ & $548 / 9952$ & 1.03 (0.97 to 1.09$)$ \\
\hline Undefined after 1959 & & & $101 / 3602$ & & $845 / 8714$ & \\
\hline
\end{tabular}

${ }^{*}$ Smoking in spouse defined by 1959 questionnaire.

†Index of environmental tobacco smoke based on seven or eight levels of smoking in spouse.

łSmoking in spouse defined by 1965 questionnaire for 1966-72 and by 1972 questionnaire for 1973-85.

environmental tobacco smoke at that time. ${ }^{6}$ The 1999 questionnaire showed that the smoking status of spouses was directly related to a history of total exposure to environmental tobacco smoke. It also showed that the extent of misclassification of exposure was not sufficient to obscure a true association between environmental tobacco smoke and coronary heart disease among women (see tables 4 and 5 ).

Our methodology and results are fully described because of concern that the earlier analysis of coronary heart disease in CPS I ${ }^{10}$ was flawed by author bias owing to funding by the tobacco industry. ${ }^{4}$ Our results for coronary heart disease and lung cancer are consistent with those of most of the other individual studies on environmental tobacco smoke, ${ }^{4-8}$ including the results for coronary heart disease and lung cancer in the full CPS I. ${ }^{10}$ Moreover, when our results are included in a meta-analysis of all results for coronary heart disease, the summary relative risks for current and ever exposure to environmental tobacco smoke are reduced to about 1.05, indicating a weak relation.

Widowhood was strongly correlated with smoking status of spouses, owing to the reduced survival of smokers. Since widowers have higher death rates than married people, ${ }^{22}{ }^{23}$ controlling for widowhood would be expected to reduce the relative risks in this and other studies of smoking in spouses. The precise effect of widowhood due to smoking in spouses still needs to be determined, but it may partially explain the positive relative risks found in other cohorts.

\section{Conclusion}

The results of the California CPS I cohort do not support a causal relation between exposure to environ-

\section{What is already known on this topic}

Exposure to environmental tobacco smoke is generally believed to increase the risk of coronary heart disease and lung cancer among never smokers by about $25 \%$

This increased risk, based primarily on meta-analysis, is still controversial due to methodological problems

\section{What this study adds}

In a large study of Californians followed for 40 years, environmental tobacco smoke was not associated with coronary heart disease or lung cancer mortality at any level of exposure

These findings suggest that the effects of environmental tobacco smoke, particularly for coronary heart disease, are considerably smaller than generally believed

Active cigarette smoking was confirmed as a strong, dose related risk factor for coronary heart disease, lung cancer, and chronic obstructive pulmonary disease 
Table 10 1960-98 age adjusted relative risk (95\% confidence interval) of death for coronary heart disease, lung cancer, and chronic obstructive pulmonary disease among cigarette smokers compared with never smokers as function of active smoking status (cigarettes per day) in 1959

\begin{tabular}{|c|c|c|c|c|}
\hline \multirow[b]{2}{*}{ Active smoking status } & \multicolumn{2}{|c|}{ Men } & \multicolumn{2}{|c|}{ Women } \\
\hline & $\begin{array}{l}\text { No of deaths/No of } \\
\text { participants }\end{array}$ & $\begin{array}{l}\text { Age adjusted relative risk } \\
(95 \% \mathrm{CI})\end{array}$ & $\begin{array}{l}\text { No of deaths/No of } \\
\text { participants }\end{array}$ & $\begin{array}{l}\text { Age adjusted relative risk } \\
(95 \% \mathrm{Cl})\end{array}$ \\
\hline \multicolumn{5}{|l|}{ Coronary heart disease } \\
\hline Never $(1)^{\star}$ & $2561 / 10862$ & 1.00 & $6516 / 39216$ & 1.00 \\
\hline Former $(2)^{*}$ & $2579 / 10204$ & 1.18 (1.12 to 1.25$)$ & $541 / 4838$ & 0.98 (0.90 to 1.07$)$ \\
\hline \multicolumn{5}{|l|}{ Current (cigarettes/day): } \\
\hline $1-9(3)^{*}$ & $376 / 1548$ & 1.19 (1.07 to 1.33$)$ & $590 / 4687$ & 1.13 (1.04 to 1.23$)$ \\
\hline $10-19(4)^{\star}$ & $859 / 3740$ & 1.42 (1.31 to 1.53$)$ & $855 / 6691$ & 1.43 (1.33 to 1.54$)$ \\
\hline $20(5)^{*}$ & $1661 / 7186$ & 1.57 (1.48 to 1.68$)$ & $912 / 6875$ & 1.79 (1.66 to 1.92$)$ \\
\hline $21-39(6)^{*}$ & $1072 / 4789$ & 1.75 (1.63 to 1.89$)$ & $254 / 2066$ & 2.04 (1.80 to 2.32$)$ \\
\hline $40-80(7)^{\star}$ & $573 / 2621$ & 1.91 (1.74 to 2.10$)$ & $111 / 818$ & 2.38 (1.97 to 2.87$)$ \\
\hline Total of current smokers & $4541 / 19884$ & $1.53(1.45$ to 1.61$)$ & $2722 / 21137$ & $1.49(1.42$ to 1.56$)$ \\
\hline 7 level index & $9681 / 40950$ & 1.11 (1.10 to 1.12$)$ & $9804 / 65191$ & 1.14 (1.13 to 1.16$)$ \\
\hline \multicolumn{5}{|l|}{ Lung cancer } \\
\hline Never (1) & $92 / 10862$ & 1.00 & $269 / 39216$ & 1.00 \\
\hline Former (2) & $281 / 10204$ & 3.50 (2.77 to 4.43$)$ & $48 / 4838$ & 1.45 (1.06 to 1.97$)$ \\
\hline \multicolumn{5}{|l|}{ Current (cigarettes/day): } \\
\hline $1-9(3)$ & $47 / 1548$ & 4.08 (2.87 to 5.80$)$ & $62 / 4687$ & 1.98 (1.50 to 2.62$)$ \\
\hline $10-19(4)$ & $187 / 3740$ & 7.86 (6.11 to 10.11$)$ & $205 / 6691$ & 5.07 (4.19 to 6.12$)$ \\
\hline $20(5)$ & $535 / 7186$ & 12.50 (9.99 to 15.63$)$ & $355 / 6875$ & 9.14 (7.73 to 10.81$)$ \\
\hline $21-39(6)$ & $424 / 4789$ & 16.43 (12.99 to 20.77 ) & $162 / 2066$ & 15.14 (12.26 to 18.69$)$ \\
\hline $40-80(7)$ & $241 / 2621$ & 18.65 (14.47 to 24.02 ) & $62 / 818$ & 15.77 (11.80 to 21.06$)$ \\
\hline Total of current smokers & $1434 / 19884$ & 11.91 (9.64 to 14.73 ) & $846 / 21137$ & 6.22 (5.39 to 7.16$)$ \\
\hline 7 level index & $1807 / 40950$ & 1.54 (1.50 to 1.58$)$ & $1163 / 65191$ & 1.69 (1.63 to 1.74$)$ \\
\hline \multicolumn{5}{|c|}{ Chronic obstructive pulmonary disease } \\
\hline Never (1) & $103 / 10862$ & 1.00 & $296 / 39216$ & 1.00 \\
\hline Former (2) & $179 / 10204$ & 2.06 (1.62 to 2.63 ) & $48 / 4838$ & 1.42 (1.05 to 1.94$)$ \\
\hline \multicolumn{5}{|l|}{ Current (cigarettes/day) } \\
\hline $1-9(3)$ & $35 / 1548$ & 2.84 (1.94 to 4.17$)$ & $50 / 4687$ & 1.64 (1.21 to 2.22$)$ \\
\hline $10-19(4)$ & $125 / 3740$ & 5.46 (4.19 to 7.11$)$ & $214 / 6691$ & 5.69 (4.73 to 6.85$)$ \\
\hline $20(5)$ & $326 / 7186$ & 8.30 (6.62 to 10.40$)$ & $309 / 6875$ & 9.32 (7.85 to 11.06$)$ \\
\hline $21-39(6)$ & $258 / 4789$ & 11.99 (9.39 to 15.31$)$ & $106 / 2066$ & 12.87 (10.13 to 16.35$)$ \\
\hline $40-80(7)$ & $148 / 2621$ & 13.54 (10.33 to 17.75$)$ & $46 / 818$ & 15.33 (11.06 to 21.23 ) \\
\hline Total of current smokers & $892 / 19884$ & 8.08 (6.58 to 9.94$)$ & $725 / 21137$ & 5.98 (5.19 to 6.89 ) \\
\hline 7 level index & $1174 / 40950$ & 1.55 (1.51 to 1.60$)$ & $1069 / 65191$ & 1.67 (1.62 to 1.73$)$ \\
\hline
\end{tabular}

*Values in parentheses are index level of active cigarette smoking.

mental tobacco smoke and tobacco related mortality, although they do not rule out a small effect. Given the limitations of the underlying data in this and the other studies of environmental tobacco smoke and the small size of the risk, it seems premature to conclude that environmental tobacco smoke causes death from coronary heart disease and lung cancer.

We thank Lawrence Garfinkel and Clark W Heath Jr (former vice presidents for epidemiology and statistics, American Cancer Society) for facilitating the extended follow up of CPS I and for making helpful comments and suggestions and Saman Assefi and Parveen Sra for technical assistance.

Contributors: JEE conceived the study and obtained funding, conducted the extended follow up, analysed the data, and drafted the manuscript; he will act as guarantor for the paper. GCK contributed to the follow up questionnaire, advised on the data analysis and interpretation, and contributed extensively to the manuscript.

Funding: The American Cancer Society initiated CPS I in 1959, conducted follow up until 1972, and has maintained the original database. Extended follow up until 1997 was conducted at the University of California at Los Angeles with initial support from the Tobacco-Related Disease Research Program, a University of California research organisation funded by the Proposition 99 cigarette surtax (www.ucop.edu/srphome/trdrp). After continuing support from the Tobacco-Related Disease Research Program was denied, follow up through 1999 and data analysis were conducted at University of California at Los Angeles with support from the Center for Indoor Air Research, a 1988-99 research organisation that received funding primarily from US tobacco companies. ${ }^{24}$

Competing interests: In recent years JEE has received funds originating from the tobacco industry for his tobacco related epidemiological research because it has been impossible for him to obtain equivalent funds from other sources. GCK never received funds originating from the tobacco industry until last year, when he conducted an epidemiological review for a law firm which has several tobacco companies as clients. He has served as a consultant to the University of California at Los Angeles for this paper. JEE and GCK have no other competing interests. They are both lifelong non-smokers whose primary interest is an accurate determination of the health effects of tobacco.

1 Taylor AE, Johnson DC, Kazemia H. Environmental tobacco smoke and cardiovascular disease. Circulation 1992;86:1-4.

2 National Cancer Institute. Health effects of exposure to environmental tobacco smoke: the report of the California Environmental Protection Agency. Smoking and Tobacco Control Monograph No 10. Bethesda, MD: US Department of Health and Human Services, National Institutes of Health, National Cancer Institute, 1999. (NIH Publication No 99-4645.)

3 US Department of Health and Human Services. Women and smoking: $a$ report of the surgeon general-2001. Washington, DC: Government Printing Office, 2001:343-67.

4 Law MR, Morris JK, Wald NJ. Environmental tobacco smoke exposure and ischaemic heart disease: an evaluation of the evidence. $B M J$ 1997;315:973-80.

5 He J, Vupputuri S, Allen K, Prerost MR, Hughes J, Whelton PK. Passive smoking and the risk of coronary heart disease-a meta-analysis of epidemiologic studies. N Engl J Med 1999;340:920-6.

6 Thun M, Henley J, Apicella L. Epidemiologic studies of fatal and nonfatal cardiovascular disease and ETS exposure from spousal smoking. Environ Health Perspect 1999;107(suppl 6):841-6. 
7 US Environmental Protection Agency. Respiratory health effects of passive smoking: lung cancer and other disorders. Washington, DC: Office of Research and Development, Office of Health and Environmental Assessment, 1992. (EPA 600/6-90/006F and NIH Publication No 93-3605.)

8 Hackshaw AK, Law MR, Wald NJ. The accumulated evidence on lung cancer and environmental tobacco smoke. BMJ 1997;315:980-8.

9 Bailar JC. Passive smoking, coronary heart disease, and meta-analysis. $N$ Engl J Med 1999;340:958-9.

10 LeVois ME, Layard MW. Publication bias in the environmental tobacco smoke/coronary heart disease epidemiologic literature. Regul Toxicol Pharmacol 1995;21:184-91.

11 LeVois ME, Layard MW. Passive smoking and heart disease [letter]. BMJ 1998;317:344-6.

12 Fleiss JL, Gross AJ. Meta-analysis in epidemiology, with special reference to studies of the association between exposure to environmental tobacco smoke and lung cancer: a critique. J Clin Epidemiol 1991;44:127-39.

13 Lee PN. Environmental tobacco smoke and mortality. Basel: Karger, 1992

14 Gori GB, Luik JC. Passive smoke: the EPA's betrayal of science and policy. Vancouver, Canada: Fraser Institute, 1999

15 Hammond EC. Smoking in relation to death rates of one million men and women. Natl Cancer Inst Monogr 1966;19:127-204.

16 Garfinkel L. Time trends in lung cancer mortality among nonsmokers and a note on passive smoking. J Natl Cancer Inst 1981;66:1061-6.

17 Burns DM, Shanks TG, Choi W, Thun MJ, Heath CW Jr, Garfinkel L. The American Cancer Society Cancer Prevention Study I: 12-year follow up of 1 million men and women. Smoking and Tobacco Control Monograph No 8. Rockville, MD: US Department of Health and Human Services, National Institutes of Health, National Cancer Institute, 1997:113-304. (NIH Publication No 97-4213.)

18 Enstrom JE, Heath CW Jr. Smoking cessation and mortality trends among 118,000 Californians, 1960-97. Epidemiology 1999;10:500-12.

19 Schall LC, Buchanich JM, Marsh GM, Bittner GM. Utilizing multiple vita status tracing services optimizes mortality follow-up in large cohort studies. Ann Epidemiol 2001;11:292-6.

20 So Y. The PHREG procedure. In: SAS/STAT software. SAS technical report P-229. Cary, NC: SAS Institute, 1992

21 Enstrom JE, Godley FH. Cancer mortality among a representative sample of nonsmokers in the United States during 1966-68. J Natl Cancer Inst 1980;65:1175-83.

22 Schaefer C, Quesenberry CP, Wi S. Mortality following conjugal bereavement and the effects of a shared environment. Am I Epidemiol 1995;141:1142-52

23 Johnson NJ, Backlund E, Sorlie PD, Loveless CA. Marital status and mortality: the national longitudinal mortality study. Ann Epidemio 2000;10:224-38

24 Green CR. Funding by the Center for Indoor Air Research (CIAR). J Health Polit Policy Law 1997;22:1279-93.

(Accepted 7 March 2003) 